\title{
Effects of different types of zinc supplement on the growth, incidence of diarrhea, immune function, and rectal microbiota of newborn dairy calves
}

\author{
M. N. Chang, J. Y. Wei, L. Y. Hao, F. T. Ma, H. Y. Li, S. G. Zhao, and P. Sun* (i) \\ State Key Laboratory of Animal Nutrition, Institute of Animal Science, Chinese Academy of Agricultural Sciences, Beijing, 100193, P. R. China
}

\begin{abstract}
Neonatal diarrhea in dairy calves causes huge economic and productivity losses in the dairy industry. Zinc is an effective anti-diarrheal agent, but high doses may pose a threat to the environment. Therefore, we aimed to evaluate the effects of low-dose zinc supplementation on the growth, incidence of diarrhea, immune function, and rectal microbiota of newborn Holstein dairy calves. Thirty newborn calves were allocated to either a control group (without extra zinc supplementation), or groups supplemented with either $104 \mathrm{mg}$ of zinc oxide ( $\mathrm{ZnO}$, equivalent to $80 \mathrm{mg}$ of zinc/d) or $457 \mathrm{mg}$ of zinc methionine (Zn-Met, equivalent to $80 \mathrm{mg}$ of zinc/d) and studied them for $14 \mathrm{~d}$. The rectal contents were sampled on d 1, 3, 7, and 14, and blood samples were collected at the end of the study. Supplementation with $\mathrm{ZnO}$ reduced the incidence of diarrhea during the first $3 \mathrm{~d}$ of life, and increased serum IgG and IgM concentrations. The Zn-Met supplementation increased growth performance and reduced the incidence of diarrhea during the first $14 \mathrm{~d}$ after birth. The results of fecal microbiota analysis showed that Firmicutes and Proteobacteria were the predominant phyla, and Escherichia and Bacteroides were the dominant genera in the recta of the calves. As the calves grew older, rectal microbial diversity and composition significantly evolved. In addition, dietary supplementation with $\mathrm{ZnO}$ reduced the relative abundance of Proteobacteria in 1-d-old calves, and increased that of Bacteroidetes, Lactobacillus, and Faecalibacterium in 7-d-old calves, compared with the control group. Supplementation with Zn-Met increased the relative abundance of the phylum Actinobacteria and the genera Faecalibacterium and Collinsella on d 7, and that of the genus Ruminococcus after 2 wk, compared with the control group. Thus, the rectal microbial composition was not affected by zinc supplementation but significantly evolved during the calves' early life.
\end{abstract}

Received September 19, 2019.

Accepted February 17, 2020.

*Corresponding author: sunpeng02@caas.cn
Zinc supplementation reduced the incidence of diarrhea in young calves. In view of their differing effects, we recommend $\mathrm{ZnO}$ supplementation for dairy calves during their first $3 \mathrm{~d}$ of life and Zn-Met supplementation for the subsequent period. These findings suggest that zinc supplementation may be an alternative to antibacterial agents for the treatment of newborn calf diarrhea.

Key words: zinc, growth, diarrhea, rectal microbiota, dairy calf

\section{INTRODUCTION}

Neonatal diarrhea frequently occurs in dairy calves around the world, and causes huge economic and productivity losses in the dairy industry (Pourliotis et al., 2012; El-Seedy et al., 2016; Wagner, 2017). Furthermore, even when calves recover from diarrhea, they may demonstrate subsequent growth impairment, which influences adult productivity (Heinrichs and Heinrichs, 2011; Morrison, 2011). Feed supplementation is commonly used to reduce the incidence of diarrhea and improve calf health. Therefore, it is important to identify effective antidiarrheal agents for use in dairy farming, especially following the prohibition of antibiotic growth promoters in the European Union (Wang et al., 2018a).

Zinc is involved in many biological processes and has been considered an effective anti-inflammatory and anti-diarrheal agent (Oteiza and Mackenzie, 2005; $\mathrm{Hu}$ et al., 2013; Bonaventura et al., 2015). Oral zinc supplementation has been used in the prevention and treatment of diarrhea in infants and children, but also in animals (Glover et al., 2013; Liberato et al., 2015; Feldmann et al., 2019), because it improves immune function, reduces the number of pathogenic bacteria, and increases the relative abundance of beneficial gastrointestinal microbes (Fairbrother et al., 2005; Sales, 2013). At present, 2 principal forms of zinc are used: inorganic zinc sources, such as zinc oxide $(\mathrm{ZnO})$, and organic zinc sources, such as zinc methionine (ZnMet). Zinc oxide, especially when administered at a high dose, promotes growth and immunity and reduces the incidence of diarrhea (Fairbrother et al., 2005; Pettigrew, 2006; Mattioli et al., 2018). Furthermore, some 
research has shown that an appropriate amount of $\mathrm{ZnO}$ increases the relative abundance of Escherichia coli (Bednorz et al., 2013) but decreases that of Lactobacillus in the gut of weaned piglets (Hojberg et al., 2005). However, organic zinc shows higher bioavailability, and better absorption and utilization by ruminants, especially when the zinc is coupled with AA (Nayeri et al., 2014; Ishaq et al., 2019). Zinc methionine has been shown to improve the performance of lambs (Garg et al., 2008; Pal et al., 2010), and Pal et al. (2010) demonstrated that Zn-Met supplementation promotes gastrointestinal tract development in ewes, secondary to better gut absorption and lower fecal losses, implying better nutrient utilization. Therefore, we hypothesized that dietary zinc supplementation would reduce the incidence of diarrhea and promote growth in dairy calves by improving the composition of the gastrointestinal microbiota.

Because of the environmental impact of zinc, the Ministry of Agriculture and Rural Affairs of China banned the supplementation of animal feed with high levels of $\mathrm{ZnO}$ in 2017. The new standard states that the zinc content of the ration of calves should be less than $180 \mathrm{mg} / \mathrm{kg}$, but the optimal dose of zinc required by neonatal calves is unclear. Recent research has shown that a lower level of organic zinc supplementation has a positive effect on the performance, antioxidant status, and immune function of calves (Glover et al., 2013; Feldmann et al., 2019; Sun et al., 2019). However, little information is available in the literature regarding the effect of zinc on the incidence of diarrhea or on the gastrointestinal microbiota in newborn calves. Therefore, in the present study, we supplemented newborn calf diets with the same low concentrations of zinc in the form of either $\mathrm{ZnO}$ or $\mathrm{Zn}-\mathrm{Met}$, and compared their effects on growth performance, the incidence of diarrhea, serum immunoglobulin concentrations, and rectal microbiota. The data obtained might provide a rationale for a reduction in the use of antibacterial agents and a theoretical basis for the rational use of zinc supplementation in calf production.

\section{MATERIALS AND METHODS}

This study was carried out in accordance with the principles of the Basel Declaration and the recommendations of the Chinese Academy of Agricultural Sciences Animal Care and Use Committee (Beijing, China). The experimental protocol was approved by the Ethics Committee of the Chinese Academy of Agricultural Sciences (Beijing, China). The study was conducted between September and December in 2016 at Beijing Sino Farm (Beijing, China). The calves were maintained according to the standards of the Chinese Academy of Agricultural Sciences Animal Care and Use Committee. The health of the calves was monitored and recorded after birth and throughout the experimental period.

\section{Animals and Diet}

Thirty newborn female Holstein dairy calves (initial BW, $40.2 \pm 1.6 \mathrm{~kg}$ ) were randomly allocated to 3 groups of 10 calves each using a random number generator (Microsoft Corp., Redmond, WA). All the calves were removed from their dams immediately after birth and housed in individual pens $(1.8 \times 1.4 \times 1.2 \mathrm{~m})$, which were bedded with straw and had iron fences to avoid cross-contamination. Calves were fed $4 \mathrm{~L}$ of colostrum from a bottle within $1 \mathrm{~h}$ of birth. The calves were fed $2 \mathrm{~L}$ of raw milk twice a day from a bottle at 0830 and $1600 \mathrm{~h}$ on d 2 and 3 , and $8 \mathrm{~L}$ of raw milk was fed from d 4 to 14. A starter concentrate, provided by Beijing Sanyuan Seed Technology Co., Ltd. (Beijing, China), was fed to the calves from d 4 . All the calves received the same colostrum and milk. The Zn-Met is an organic zinc preparation that was prepared by Daiyuan, Shanghai (purity $\geq 98 \%$ ). The ingredients and chemical composition of the starter are shown in Table 1.

Table 1. Ingredients and chemical composition of the starter

\begin{tabular}{lc}
\hline Item & Value \\
\hline Ingredient, g/kg of DM & \\
Corn & 378 \\
Chinese wildrye hay & 202 \\
Soybean cake & 182 \\
Wheat bran & 28 \\
Wheat middlings & 78 \\
Molasses & 16 \\
Ground oyster shell & 16 \\
Salt & 8 \\
Bentonite & 8 \\
Calcium phosphate & 12 \\
Extruded soybean & 64 \\
Premix & 8 \\
Chemical analysis & \\
DM, g/kg & 895 \\
CP, g/kg & 200 \\
Ether extract, g/kg & 28 \\
ADF, g/kg & 100 \\
NDF, g/kg & 180 \\
Ash, g/kg & 67 \\
Zn, mg/kg & 172 \\
\hline
\end{tabular}

${ }^{1}$ Premix provided per kilogram of diet: vitamin A, 1,000,000 IU; vitamin D, 270,000 IU; vitamin E, 2,900 IU; Cu, 5,000 mg; Fe, 9,000 mg; $\mathrm{Zn}, 8,000 \mathrm{mg} ; \mathrm{Mn}, 6,000 \mathrm{mg}$; Se, $67 \mathrm{mg} ; \mathrm{I}, 227 \mathrm{mg}$; Co, $20 \mathrm{mg}$; Mg, $9,800 \mathrm{mg}$. 


\section{Experimental Design and Sample Collection}

At the beginning of the trial, the concentrations of zinc in the water, milk, and starter were determined. No zinc was detectable in the water, and the concentrations present in the milk and starter were 4.12 and $172 \mathrm{mg} / \mathrm{kg}$, respectively. The zinc was provided in the starter in the form of zinc sulfate. The control calves were fed starter that was not supplemented with $\mathrm{ZnO}$ or Zn-Met, and the calves in the treatment groups received either $104 \mathrm{mg}$ of $\mathrm{ZnO}$ (analytical-grade; SigmaAldrich, Taufkirchen, Germany; yielding $80 \mathrm{mg} / \mathrm{d}$ zinc) or $457 \mathrm{mg}$ of Zn-Met (feed grade; http://www.finechem -china.com/; yielding $80 \mathrm{mg} / \mathrm{d}$ zinc) daily. This level of zinc supplementation was determined on the basis of previous publications (Glover et al., 2013; Feldmann et al., 2019; Wei et al., 2019). The appropriate amount of $\mathrm{ZnO}$ or Zn-Met was mixed with $200 \mathrm{~mL}$ of milk, and administered to each calf using an oral dispenser, after which more milk was fed. The trial lasted for $14 \mathrm{~d}$, during which all the animals had free access to fresh water and starter concentrate.

Blood samples were obtained from each calf by jugular vein puncture using $10-\mathrm{mL}$ gel vacuum tubes on the morning of $\mathrm{d} 15$. These blood samples were centrifuged for $15 \mathrm{~min}$ at $3,000 \times \mathrm{g}$ at $4^{\circ} \mathrm{C}$ using a high-speed freezing centrifuge (Eppendorf 5810R, Eppendorf AG, Hamburg, Germany). The supernatant was collected and stored at $-80^{\circ} \mathrm{C}$ for subsequent total serum IgA, $\operatorname{IgG}$, and $\operatorname{IgM}$ measurement.

Fecal samples were collected from the rectum on the mornings of $\mathrm{d} 1,3,7$, and 14 of the trial for subsequent analysis of the microbiota. Before collection of the samples, centrifuge tubes (Corning, NY) were sterilized using UV light (Longpro Co. Ltd., Guangzhou, China). Stainless-steel trays $(20 \times 27 \times 2 \mathrm{~cm})$ were sterilized using an autoclave and used to collect fresh feces, which were immediately placed on ice for sorting and marking. The fecal samples were cut up using glass slides (Sinopharm Chemical Reagent Co., Ltd., Shanghai, China) and collected into the aseptic centrifuge tubes. About $0.2 \mathrm{~g}$ of feces was collected into each 2 -mL tube and 10 tubes were filled for each animal. These fecal samples were snap-frozen in liquid nitrogen and then stored at $-80^{\circ} \mathrm{C}$ until use.

\section{Analysis of Growth Performance and the Incidence of Diarrhea}

The ADG was calculated by weighing the calves on $\mathrm{d}$ 1 and 14, and the DMI of milk and starter was recorded throughout the trial. The starter was sampled for the analysis of DM content (AOAC International, 2005; method 930.15), CP (AOAC International, 2000; method 976.05), and ether extract (AOAC International, 2003; method 4.5.05) using the standard procedures of AOAC International. The NDF and ADF contents were determined as described by Van Soest et al. (1991).

Fecal character was scored on a 1 to 4 scale, where 1 was normal, 2 was pasty, 3 was semi-liquid, and 4 was liquid with an abnormal color (Teixeira et al., 2015). Scores 1 and 2 were considered normal. Diarrhea was defined as the presence of grade 3 or 4 feces for 2 consecutive days (Marcondes et al., 2016). The incidence of diarrhea in each group was calculated using the following formula:

\section{incidence of diarrhea $(\%)=$ \\ diarrhea calves in each group $\times$ diarrhea days $\times 100 \%$. total calves in each group $\times$ experimental days \\ Analysis of Total Serum IgA, IgG, and IgM Concentrations by ELISA}

The total serum IgA, IgG, and IgM antibody concentrations were determined using bovine ELISA kits purchased from Bethyl Laboratories (Montgomery, TX), according to the manufacturer's instructions.

\section{Total DNA Extraction from Rectal Microbes}

Cetyl trimethyl ammonium bromide (CTAB) and bead-beating methods were used to extract total microbial DNA from rectal fecal samples (Sun et al., 2016). Briefly, $0.2 \mathrm{~g}$ of the rectal contents was diluted with normal saline and centrifuged at $500 \times g$ for $10 \mathrm{~min}$ at $4^{\circ} \mathrm{C}$. Then, the supernatants were centrifuged at $13,000 \times g$ for $20 \mathrm{~min}$ at $4^{\circ} \mathrm{C}$, and $800 \mu \mathrm{L}$ of CTAB lysis buffer containing $2 \%$ CTAB, $100 \mathrm{~m} M$ Tris- $\mathrm{HCl}$ $\mathrm{pH}$ 8.0, $1.4 \mathrm{M} \mathrm{NaCl}$, and $20 \mathrm{~m} M$ EDTA was added to the bacterial precipitate. After lysis in a Mini BeadBeater-1 (Biospec Products Inc., Bartlesville, OK), the bacterial precipitate was incubated at $70^{\circ} \mathrm{C}$ for $20 \mathrm{~min}$ and centrifuged at $13,000 \times g$ for $10 \mathrm{~min}$ at $25^{\circ} \mathrm{C}$. The DNase-free RNase was added to the new supernatants, and they were incubated for $20 \mathrm{~min}$ and then mixed with phenol:chloroform:isoamyl alcohol (25:24:1, vol/ $\mathrm{vol} / \mathrm{vol}$ ) solution for re-extraction by centrifugation at $13,000 \times g$ for $10 \mathrm{~min}$ at $4^{\circ} \mathrm{C}$. Re-extraction of the samples was performed using buffered phenol, and then the DNA was precipitated with ethanol and dissolved in Tris-EDTA buffer ( $1 M$ Tris-HCl, $0.5 M$ EDTA, $\mathrm{pH}$ 8.0). The quantity and quality of the extracted DNA were assessed using a NanoDrop ND-1000 spectropho- 
tometer (Thermo Fisher Scientific, Waltham, MA) and agarose gel electrophoresis, respectively.

\section{S rRNA Gene Sequencing}

We sequenced the V3-V4 hypervariable regions of the microbial $16 \mathrm{~S}$ rRNA genes using the primers 338F 5'-ACTCCTACGGGAGGCAGCA-3' and 806R 5'-GGACTACHVGGGTWTCTAAT-3'. The PCR conditions were as follows: initial denaturation at $95^{\circ} \mathrm{C}$ for 3 min, and then 29 cycles of $95^{\circ} \mathrm{C}$ for $30 \mathrm{~s}, 55^{\circ} \mathrm{C}$ for $30 \mathrm{~s}$, and $72^{\circ} \mathrm{C}$ for $45 \mathrm{~s}$, followed by a final extension at $72^{\circ} \mathrm{C}$ for $10 \mathrm{~min}$. The PCR reaction mixture was composed of $4 \mu \mathrm{L}$ of $5 \times$ PrimeSTAR buffer, $2 \mu \mathrm{L}$ of $2.5 \mathrm{~m} M \mathrm{dNTP}$, $0.8 \mu \mathrm{L}$ of each primer $(5 \mu M), 0.4 \mu \mathrm{L}$ of PrimeSTAR heat stress DNA polymerase (Takara, Dalian, China), and $20 \mathrm{ng}$ of template DNA in a total volume of 20 $\mu \mathrm{L}$. All the samples were assayed in triplicate. The amplicons were separated on $2 \%$ agarose gels and purified using a DNA purification kit (Axygen, Biosciences, Union City, CA). The PCR products from each sample were mixed in equal quantities and used to construct a sequencing library using an Illumina TruSeq DNA Sample Preparation Kit. Finally, the V3-V4 amplicons were sequenced using the paired-end method on an Illumina Miseq at Majorbio (Shanghai, China). The sequences were submitted to GenBank, and the accession number obtained was SRP199353.

\section{Sequence Analysis}

The QIIME (v1.9.0) was used to analyze the $16 \mathrm{~S}$ rRNA gene sequences (Caporaso et al., 2010). The raw sequencing reads with exact matches to the barcodes were assigned to their respective samples and identified as valid sequences. The low-quality sequences were filtered using the following criteria: length $<150 \mathrm{bp}$, quality score $<$ Q20, and the presence of ambiguous bases and mononucleotide repeats of $>8 \mathrm{bp}$. Then, the paired-end reads were assembled using FLASH (Magoč and Salzberg, 2011). After chimera detection using UCHIME (Haas et al., 2011), the remaining high-quality sequences were clustered into operational taxonomic units (OTU) at $97 \%$ sequence identity using UCLUST (Edgar et al., 2011). The OTU taxonomy was determined using the Ribosomal Data Project classifier, which had been retrained for the Greengenes database version 13_8 (Wang et al., 2007). The OTUlevel $\alpha$-diversity indices, including observed species, Chao1 richness estimator, Shannon index, and Simpson index, were used to assess community diversity. Betadiversity was analyzed using weighted Unifrac distance and visualized using principal coordinate analysis.

\section{Statistical Analysis}

The Durbin-Watson test was used to check the randomness of the initial $\mathrm{BW}$ data, and showed that the randomization had been effective. A chi-squared contingency test was used to compare the effect of zinc source on the prevalence of diarrhea. The growth performance, zinc intake, and serum immunoglobulin concentration data were analyzed using one-way ANOVA in the MIXED procedure of SAS 9.4 (SAS Institute Inc., Cary, NC). The rectal microbial data were analyzed on the basis of repeated measurements, and a compound symmetry variance and covariance structure using the GLIMMIX procedure of SAS 9.4. The repeated measures model contained fixed effects of treatment, day, and the interaction of treatment and day, and the random effect of calf identity. The data are presented as the least squares means and standard error of the mean. Differences between the treatment groups were identified using Tukey's multiple range test. A $P$ $\leq 0.05$ was accepted as statistically significant, and $P$-values between 0.05 and 0.10 were considered to represent a statistical trend. The relationships between the populations of the principal fecal microbes on $\mathrm{d} 14$ and the growth performance or serum immunoglobulin concentrations were analyzed using Pearson's rank correlation coefficients.

\section{RESULTS}

\section{Performance, Zinc Intake, and Incidence of Diarrhea}

No differences were observed in the initial BW of calves in the 3 groups. Supplementation with Zn-Met significantly increased the ADG of the calves compared with the control group $(P<0.05$; Table 2$)$. No differences were observed in the DMI of milk or starter, or in the zinc intake from starter between the 3 groups. However, the total zinc intake by the $\mathrm{ZnO}$ and $\mathrm{Zn}$-Met groups was much higher than that by the control group $(P<0.05)$. The addition of $\mathrm{Zn}-\mathrm{Met}$ reduced the incidence of diarrhea in calves compared with the control group ( 15.71 vs. $27.86 \%$; $P=0.05$ ). In addition, supplementation with $\mathrm{ZnO}$ reduced the incidence of diarrhea during the first $3 \mathrm{~d}$ of life $(P<0.01)$ and also tended to reduce it during d 1 to $7(P=0.08)$.

\section{Total Serum IgA, IgG, and IgM Concentrations}

The total serum IgG concentration in the $\mathrm{ZnO}$ group was significantly higher than in the control group (13.27 vs. $9.42 \mathrm{mg} / \mathrm{mL}, P<0.05)$, and the serum IgM concentration was also higher in the $\mathrm{ZnO}$ group than in the control group (5.08 vs. $2.22 \mathrm{mg} / \mathrm{mL}, P<0.05)$. 
Table 2. The growth performance, zinc intake, incidence of diarrhea, and serum immunoglobulin concentrations in Holstein dairy calves fed different sources of zinc

\begin{tabular}{|c|c|c|c|c|c|}
\hline \multirow[b]{2}{*}{ Item } & \multicolumn{3}{|c|}{ Treatment $(\text { Trt })^{1}$} & \multirow[b]{2}{*}{ SEM } & \multirow{2}{*}{$\frac{P \text {-value }}{\text { Trt }}$} \\
\hline & Control & Zn-Met & $\mathrm{ZnO}$ & & \\
\hline Initial BW, kg & 40.23 & 40.23 & 40.22 & 2.88 & 1.00 \\
\hline $\mathrm{ADG}, \mathrm{g} / \mathrm{d}$ & $538.93^{\mathrm{b}}$ & $659.29^{\mathrm{a}}$ & $597.86^{\mathrm{ab}}$ & 31.28 & 0.04 \\
\hline Starter intake, $g$ of $\mathrm{DM} / \mathrm{d}$ & 26.80 & 26.13 & 17.48 & 6.27 & 0.51 \\
\hline Total feed intake, $g$ of DM/d & 940.50 & 939.83 & 931.18 & 6.27 & 0.51 \\
\hline Zinc intake of starter, $\mathrm{mg} / \mathrm{d}$ & 4.61 & 4.49 & 3.01 & 1.08 & 0.51 \\
\hline Total zinc intake, $\mathrm{mg} / \mathrm{d}$ & $4.61^{\mathrm{b}}$ & $84.49^{\mathrm{a}}$ & $83.01^{\mathrm{a}}$ & 1.08 & $<0.01$ \\
\hline Feed efficiency, g of DMI/g of gain & 1.82 & 1.47 & 1.58 & 0.10 & 0.06 \\
\hline Incidence of diarrhea (d 1 to 3 ), $\%$ & $20.00^{\mathrm{a}}$ & $13.33^{\mathrm{a}}$ & $0^{\mathrm{b}}$ & - & $<0.01$ \\
\hline Incidence of diarrhea (d 4 to 7 ), $\%$ & 22.50 & 10.00 & 15.00 & - & 0.32 \\
\hline Incidence of diarrhea ( $\mathrm{d} 1$ to 7 ), $\%$ & 21.43 & 11.43 & 8.57 & - & 0.08 \\
\hline Incidence of diarrhea (d 8 to 14 ), $\%$ & 34.29 & 20.00 & 34.29 & - & 0.11 \\
\hline Incidence of diarrhea (d 1 to 14$), \%$ & $27.86^{\mathrm{a}}$ & $15.71^{\mathrm{b}}$ & $21.43^{\mathrm{ab}}$ & - & 0.05 \\
\hline $\mathrm{IgA}, \mu \mathrm{g} / \mathrm{mL}$ & 34.03 & 30.55 & 36.11 & 6.62 & 0.84 \\
\hline $\mathrm{IgG}, \mathrm{mg} / \mathrm{mL}$ & $9.42^{\mathrm{b}}$ & $10.09^{\mathrm{ab}}$ & $13.27^{\mathrm{a}}$ & $\begin{array}{l}0.02 \\
1.00\end{array}$ & $\begin{array}{l}0.04 \\
0.02\end{array}$ \\
\hline $\mathrm{IgM}, \mathrm{mg} / \mathrm{mL}$ & $2.22^{\mathrm{b}}$ & $1.93^{\mathrm{b}}$ & $5.08^{\mathrm{a}}$ & 0.73 & 0.01 \\
\hline
\end{tabular}

${ }^{a, b}$ Means in the same row with different superscripts are significantly different $(P \leq 0.05)$.

${ }^{1} \mathrm{Zn}$-Met $=$ zinc methionine group; $\mathrm{ZnO}=$ zinc oxide group.

However, no differences were observed in the concentrations of IgG or IgM between the Zn-Met and control groups (Table 2). The source of dietary zinc had no significant effect on the total serum IgA concentration in the newborn calves $(P>0.05)$.

\section{Rectal Microbial Diversity}

A total of 4,543,412 high-quality sequences were obtained from the rectal samples, with an average of 37,862 sequences per sample (30,121-44,988 sequences). The indicators of $\alpha$ diversity showed that the $\mathrm{ZnO}$ group had a higher number of observed species and Chao1 estimator than the control and Zn-Met groups on $\mathrm{d} 1(P \leq 0.05$, Table 3$)$. In addition, time had a significant effect on $\alpha$ diversity, but no difference was identified with respect to treatment or the interaction of treatment and time. A plot of the principal coordinate analysis scores showed great similarity between the 3 groups of rectal microbiota on d 1 and 14 (Figure 1). The diversity of the microbiota in the $\mathrm{ZnO}$ group was similar to that of the control group on $\mathrm{d} 3$ and 7, whereas the Zn-Met group demonstrated a marked shift along principal component 1 compared with the control group (Figure 1).

\section{Relative Abundance of Bacterial Taxa}

A comparison of the effects of $\mathrm{ZnO}$ and $\mathrm{Zn}-\mathrm{Met}$ supplementation on the rectal microbial composition of neonatal calves on different days was carried out using a taxon-dependent analysis. Firmicutes and Proteobacteria were the dominant phyla, followed by Bacteroide- tes, Fusobacteria, Actinobacteria, and Verrucomicrobia (Figure 2A, B). However, as the calves grew older, the relative abundances of all these phyla changed significantly $(P<0.01$; Table 4$)$. A trend toward greater relative abundance of Firmicutes was identified for calves fed $\mathrm{ZnO}$ compared with the control group on d 1 ( $P$ $<0.10)$. However, the relative abundance of Proteobacteria in the 1-d-old $\mathrm{ZnO}$-administered calves was lower than that in the control and Zn-Met-administered calves of the same age $(P=0.05)$. In addition, the relative abundance of Bacteroidetes was higher in the $\mathrm{ZnO}$ group than in the other 2 groups at the age of $7 \mathrm{~d}(P$ $<0.05)$. The relative abundance of Actinobacteria was significantly higher in the Zn-Met group than in the control group during the first week $(P<0.05)$.

Escherichia and Bacteroides were the predominant genera, followed by Peptostreptococcus, Butyricicoccus, Faecalibacterium, Dorea, Lactobacillus, Fusobacterium, Klebsiella, Blautia, Akkermansia, and Clostridium (Figure 2C, D). The relative abundances of Butyricicoccus and Dorea tended to be higher in the $\mathrm{ZnO}$ than in the control groups when they were $3 \mathrm{~d}$ old $(P<0.10$; Table 5). The relative abundance of Lactobacillus in the $\mathrm{ZnO}$ group was higher than that in the control group on $\mathrm{d} 7(P<0.05)$. The relative abundance of Ruminococcus in the Zn-Met group was 8-fold higher than that in the control group at 2 wk $(P<0.05)$. The relative abundance of Faecalibacterium was higher in the $\mathrm{ZnO}$ and $\mathrm{Zn}$-Met groups than in the control group on $\mathrm{d} 7(P<0.05)$. The relative abundances of Klebsiella and Collinsella in the Zn-Met group were higher than in the control group on $\mathrm{d} 1$ and 7 , respectively $(P<$ $0.05)$. In addition, time had a significant effect on the 
Table 3. Effects of different sources of dietary zinc on the microbial species, richness, and diversity in the recta of dairy calves at several time points

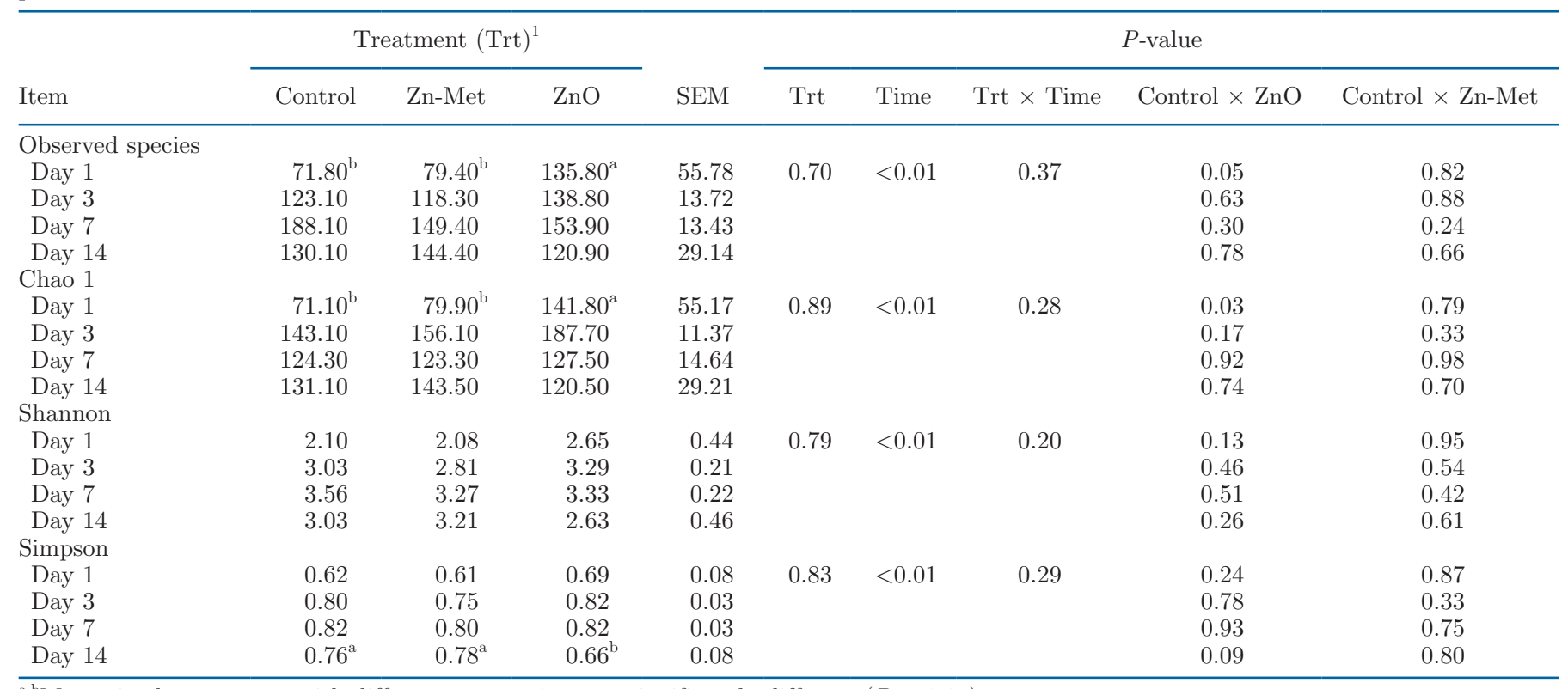

${ }^{\mathrm{a}, \mathrm{b}}$ Means in the same row with different superscripts are significantly different $(P \leq 0.05)$.

${ }^{1} \mathrm{Zn}-\mathrm{Met}=$ zinc methionine group; $\mathrm{ZnO}=$ zinc oxide group.
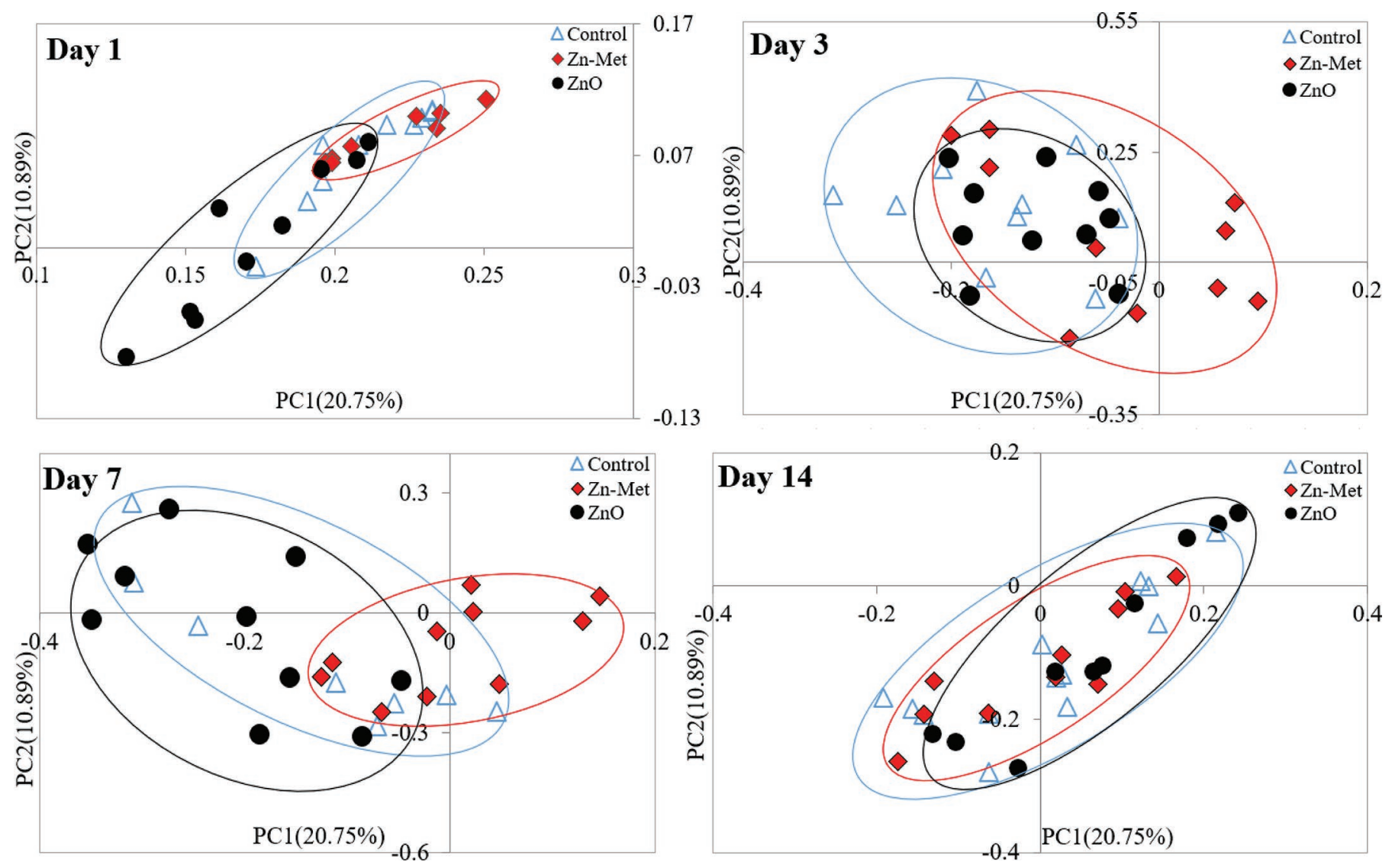

Figure 1. Principal coordinate analysis of the effect of dietary zinc source on rectal microbiota. Zn-Met $=$ zinc methionine group; ZnO $=$ zinc oxide group. $\mathrm{PC} 1=$ principal component $1 ; \mathrm{PC} 2=$ principal component 2. 
representation of each genus except for Ruminococcus $(P<0.05)$.

\section{Relationships Between the Sizes of Microbial Populations, and Growth Performance and Immunoglobulin Indices}

We next analyzed the relationships between the size of each rectal microbial population on $\mathrm{d} 14$ and both growth performance and immunoglobulin indices using Pearson's rank correlation coefficients. At the phylum level, the relative abundance of Proteobacteria negatively correlated with total feed intake and starter intake $(P<0.05$; Table 6$)$, whereas the relative abundance of Bacteroidetes positively correlated with these variables $(P<0.01)$. At the genus level, the relative abundance of Dorea positively correlated with the concentrations of IgG and $\operatorname{IgA}(P<0.05$; Table 7$)$. The ADG positively correlated with the relative abundances of Faecalibacterium $(P<0.05)$ and Akkermansia $(P<0.01)$. Finally, the relative abundance of Blautia positively correlated with total feed intake and starter intake, but negatively correlated with IgG concentration $(P<0.05)$.

\section{DISCUSSION}

The present study showed that supplementation with $\mathrm{Zn}-\mathrm{Met}$, but not $\mathrm{ZnO}$, significantly increased the ADG of newborn calves in the first 2 wk after birth. Although the growth-promoting effect of organic zinc has been shown to be greater than that of inorganic zinc (El-Nour et al., 2010; Hill et al., 2014), the effect of $\mathrm{Zn}-\mathrm{Met}$ and $\mathrm{ZnO}$ on the growth performance of cattle has also been shown to be comparable in another study (Spears, 1989). In the present study, calves gained $120.36 \mathrm{~g} / \mathrm{d}$ in the Zn-Met group and $58.93 \mathrm{~g} / \mathrm{d}$ in the $\mathrm{ZnO}$ group more than those in the control group, which is consistent with the findings of Glover et al. (2013), who showed that calves gained $40.24 \mathrm{~g} / \mathrm{d}$ when receiving $80 \mathrm{mg}$ of zinc from Zn-Met, but they also showed no differences between $\mathrm{Zn}-\mathrm{Met}, \mathrm{ZnO}$, and placebo treatments. Feldmann et al. (2019) also found that
A
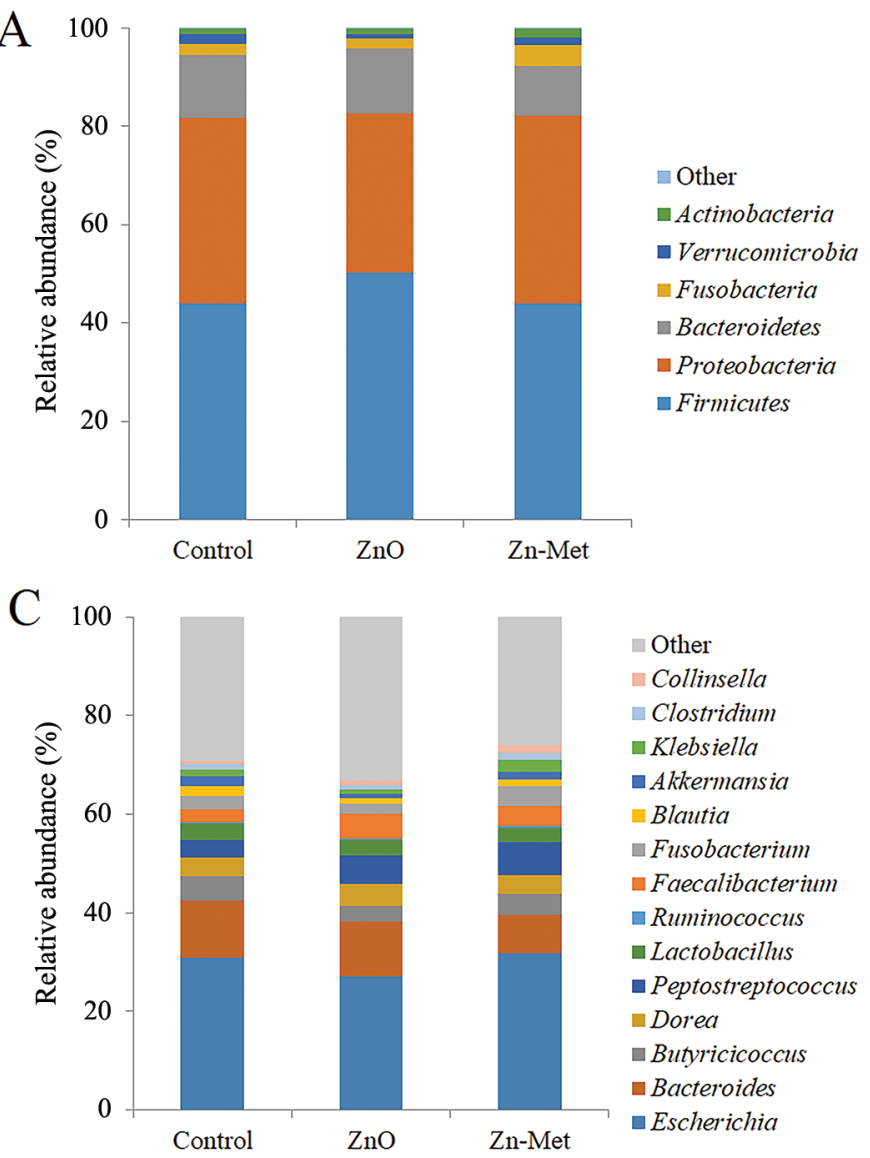

B

D
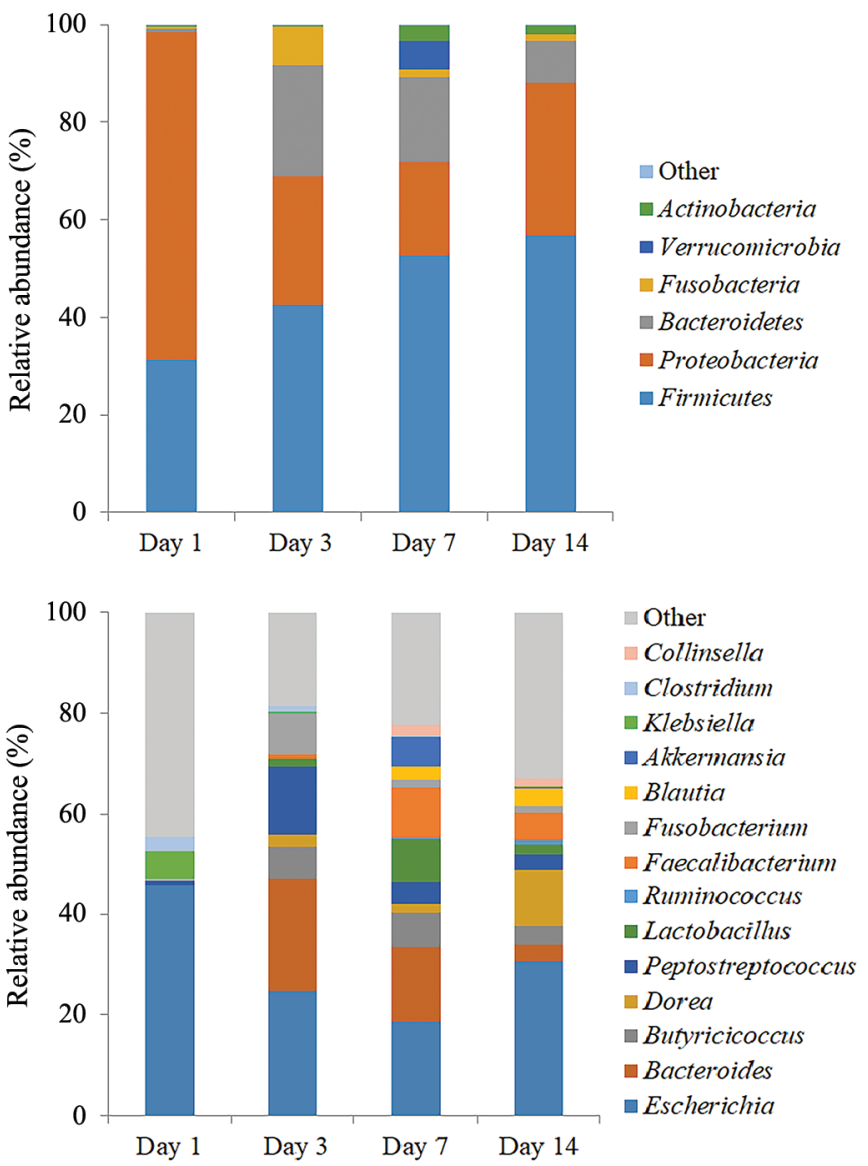

Figure 2. Composition of the rectal microbial community. (A) and (C) show the composition of the microbial community in the 3 groups (control, $\mathrm{ZnO}$, and $\mathrm{Zn}-\mathrm{Met}$ ) with respect to the phyla and genera. (B) and (D) show the compositions at 4 time points during the study (d 1, $3,7$, and 14$)$. Zn-Met = zinc methionine group; $\mathrm{ZnO}=$ zinc oxide group. 
Table 4. Taxonomic analysis of the principal rectal phyla in Holstein dairy calves, classified according to zinc source and time point

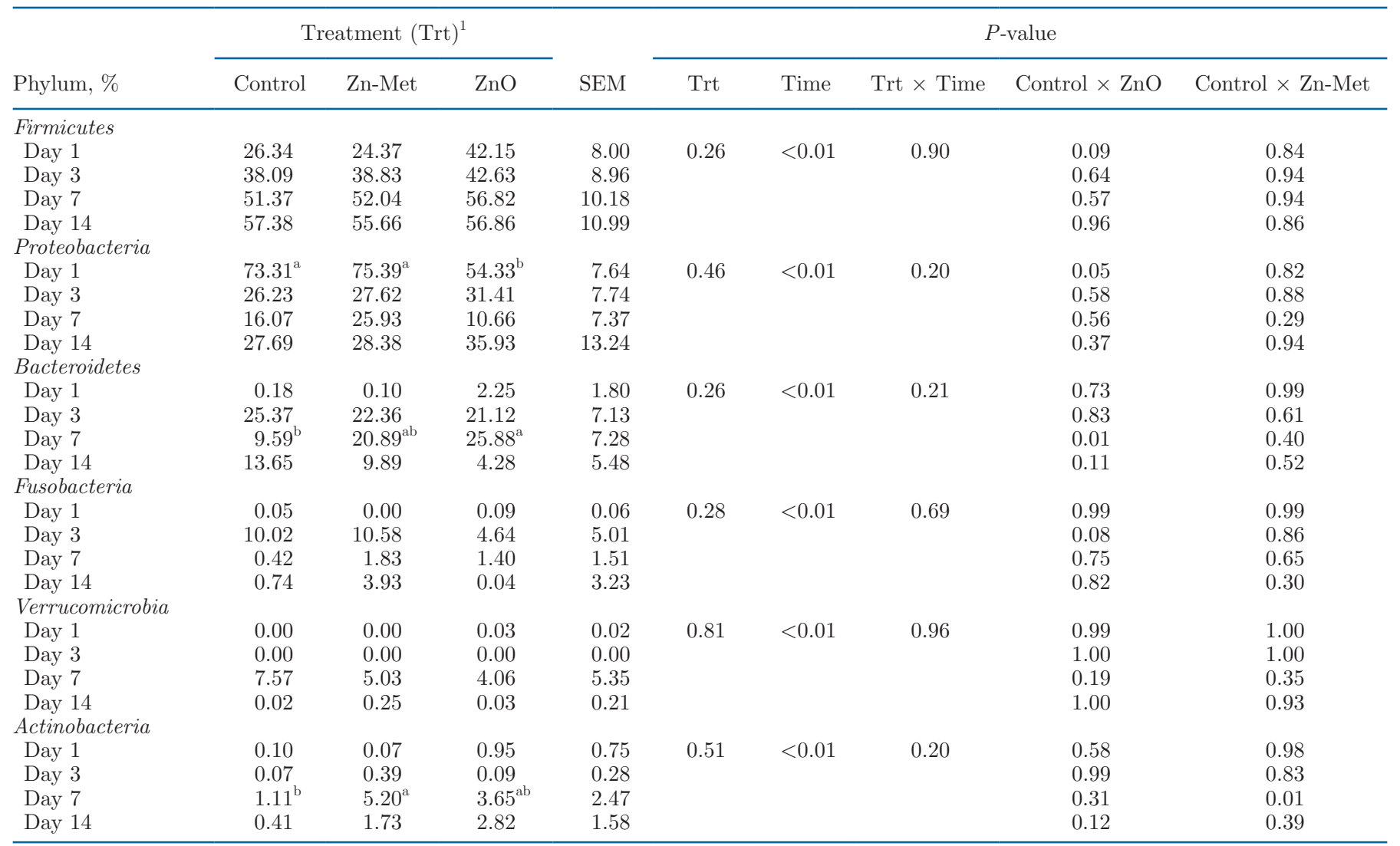

${ }^{\mathrm{a}, \mathrm{b}}$ Means in the same row with different superscripts are significantly different $(P \leq 0.05)$.

${ }^{1} \mathrm{Zn}-\mathrm{Met}=$ zinc methionine group; $\mathrm{ZnO}=$ zinc oxide group.

Zn-Met-treated bull calves had a $22 \mathrm{~g} / \mathrm{d}$ higher ADG than placebo-treated bull calves. Spears (1989) found that growth performance did not differ between heifers fed $\mathrm{ZnO}$ or $\mathrm{Zn}$-Met, although it tended to be higher in the latter group. Notably, the feed-to-gain ratio in the Zn-Met group tended to be lower than in the control group, which might be due to the higher bioavailability of Zn-Met. The Zn-Met is a chelate of methionine and inorganic zinc, and it may therefore have the dual effects of Met and zinc. Methionine is one of the main limiting AA for ruminant growth (Hill et al., 2008) and plays an important role in metabolism. About $52 \%$ of Met is metabolized by intestinal lumen cells, where it is converted to cysteine (Wu et al., 1998), which promotes performance (Jankowski et al., 2014; Chagas et al., 2018). However, the individual and joint actions of Met and zinc in Zn-Met require further investigations.

In the present study, the incidence of diarrhea in control calves fluctuated between 20 and $34.29 \%$ during the first 2 wk of life. However, supplementation with $\mathrm{ZnO}$ or $\mathrm{Zn}-\mathrm{Met}$ helped to reduce the incidence of diarrhea in neonatal dairy calves during their early lives. We observed no diarrhea in calves in the $\mathrm{ZnO}$ group during the first $3 \mathrm{~d}$ after birth, which is consistent with previous findings (Wang et al., 2018b; Sun et al., 2019). In addition, supplementation with Zn-Met reduced the incidence of diarrhea, which is consistent with the results obtained by Feldmann et al. (2019), who showed that Zn-Met-treated calves had a $14.7 \%$ lower risk of diarrhea than placebo-treated calves.

Many studies have shown that zinc is a gatekeeper of immune function (Keen and Gershwin, 1990; Wessels et al., 2017). The anti-diarrheal function of zinc may be associated with its role in immunity (Bonaventura et al., 2015; Pei et al., 2019). The concentrations of circulating immunoglobulins, especially $\operatorname{IgG}$, IgM, and $\operatorname{IgA}$, are important indicators of immune function. Immunoglobulin $\mathrm{G}$ is the main antibody mediating humoral immunity and is the most abundant antibody in the serum (Crassini et al., 2018), whereas IgM is the first antibody to appear in immune responses and infection (Ehrenstein and Notley, 2010), and IgA is the principal antibody in exocrine secretions (Woof and Kerr, 2006). Some investigators have proposed that supplementation with zinc increases the immune responsiveness of calves by increasing $\operatorname{IgG}$ concentration (Kegley et al., 2001; 
Table 5. Taxonomic analysis of the principal rectal genera in Holstein dairy calves, classified according to zinc source and time point

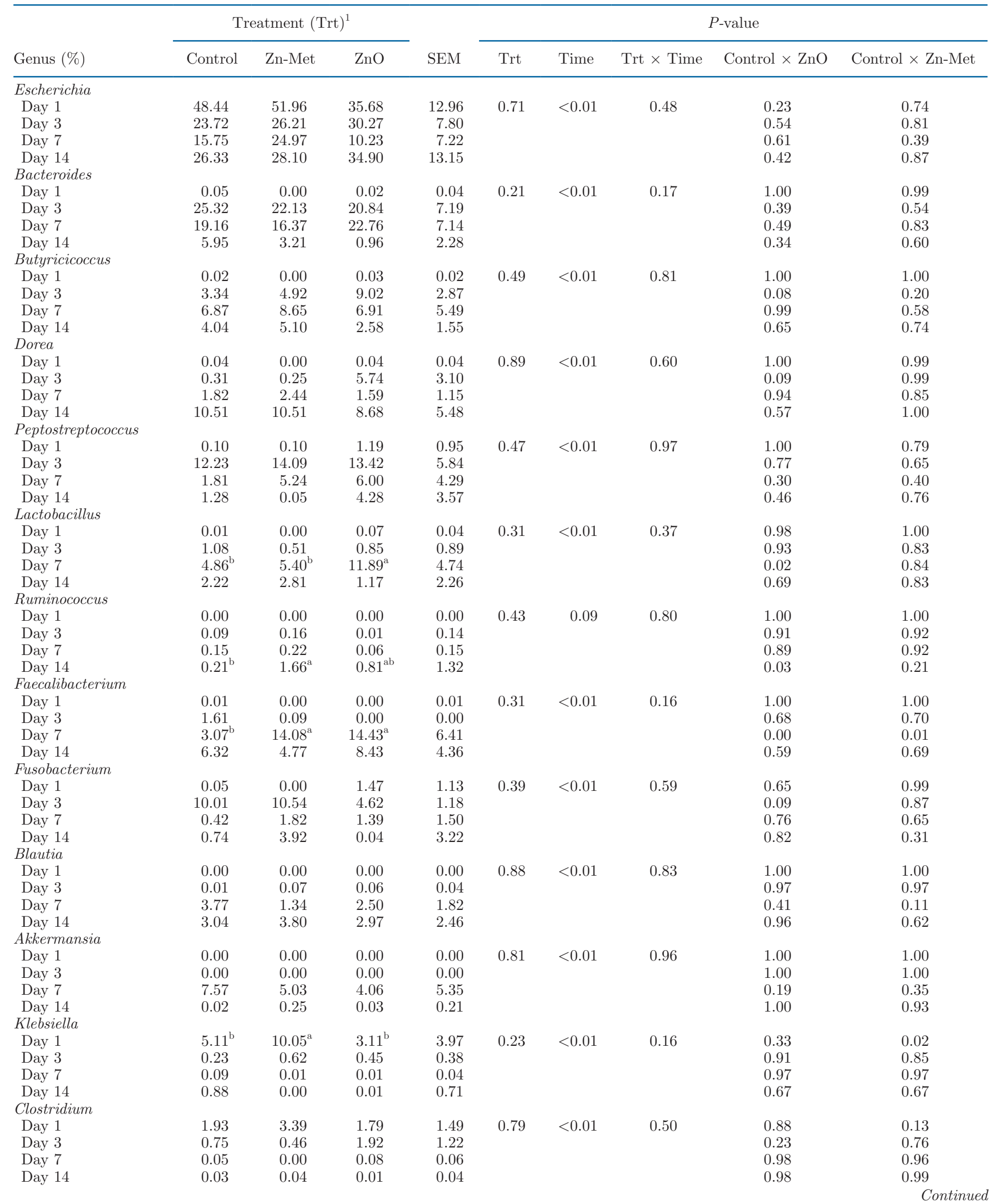


Table 5 (Continued). Taxonomic analysis of the principal rectal genera in Holstein dairy calves, classified according to zinc source and time point

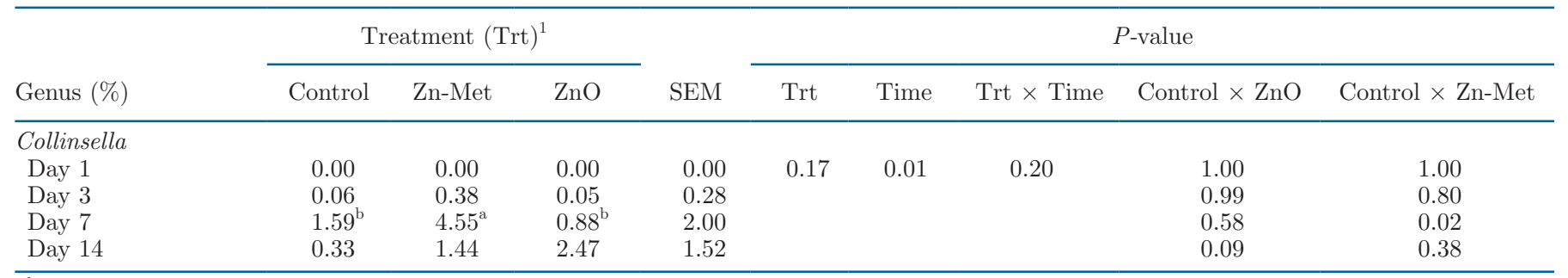

${ }^{\mathrm{a}, \mathrm{b}}$ Means in the same row with different superscripts are significantly different $(P \leq 0.05)$.

${ }^{1} \mathrm{Zn}-\mathrm{Met}=$ zinc methionine group; $\mathrm{ZnO}=$ zinc oxide group.

Tomasi et al., 2018), whereas others have shown that supplementation with coated $\mathrm{ZnO}$ at 380 or $570 \mathrm{mg}$ of $\mathrm{Zn} / \mathrm{kg}$ reduces diarrhea index and increases secretory IgA concentration in the jejunal mucosa (Shen et al., 2014). Furthermore, Nagalakshmi et al. (2018) demonstrated that administration of a low level of organic zinc improves growth performance and the immune response of calves. Consistent with these findings, we found that $\mathrm{ZnO}$ supplementation increased serum IgG and IgM concentrations above those of the control by 3.85 and $2.86 \mathrm{mg} / \mathrm{mL}$, respectively, compared with $\mathrm{Zn}$ Met supplementation, indicating that the administration of a low level of $\mathrm{ZnO}$ is superior to $\mathrm{Zn}$-Met with respect to the immune function of dairy calves.

The mechanisms of the anti-diarrheal effect of zinc are thought to involve the regulation of intestinal fluid transport and mucosal integrity, the promotion of immunity, and the modulation of oxidative stress (Berni Canani et al., 2011; Wei et al., 2019). However, investigations of the interactions of zinc, especially a large quantity of $\mathrm{ZnO}$, with the gut microbiota have generated disparate findings (Pieper et al., 2012; Starke et al., 2014). Proteobacteria is a major phylum of gramnegative bacteria, which produces LPS endotoxin that can enter the blood, reduce the number of intestinal barrier cells, and increase intestinal permeability, leading to a chronic inflammatory response (Cani et al., 2007). Previous research has shown that a long-term increase in the population of Proteobacteria is indicative of an imbalance in the microbial community structure or the presence of disease in the host (Shin et al., 2015). In the present study, we found that the relative abundance of Proteobacteria negatively correlated with total feed intake and starter intake on d 14 . Furthermore, the relative abundance of Proteobacteria in the $\mathrm{ZnO}$ group on $\mathrm{d} 1$ was lower than that in the control and Zn-Met groups, implying that a low level of $\mathrm{ZnO}$ supplementation may inhibit the reproduction of Proteobacteria, a harmful bacterium. The effects of Bacteroidetes on the health of the host are largely beneficial and include interactions with the immune system, resulting in the activation of T-cell mediated responses (Mazmanian et al., 2008; Wen et al., 2008) and limitation of gastrointestinal tract colonization by potentially pathogenic bacteria (Mazmanian et al., 2008). In addition, Bacteroidetes species generally produce butyrate, a product of colonic fermentation that has antineoplastic properties and helps to maintain a healthy gut (Kim and Milner, 2007). They are also involved in bile acid metabolism and the transformation of toxic or mutagenic compounds. In the present study, the relative abundance of Bacteroidetes was higher in the $\mathrm{ZnO}$ group and positively correlated with total feed intake and starter intake. Actinobacteria are grampositive bacteria that can use carbohydrate to produce lactic acid. Some natural products of Actinobacteria are

Table 6. Pearson correlation coefficients between the populations of the principal phyla on d 14, and growth performance and immunoglobulin indices

\begin{tabular}{|c|c|c|c|c|c|c|c|}
\hline Phylum & $\mathrm{ADG}$ & Total feed intake & Starter intake & Feed efficiency & $\begin{array}{l}\text { Serum IgG } \\
\text { concentration }\end{array}$ & $\begin{array}{c}\text { Serum IgA } \\
\text { concentration }\end{array}$ & $\begin{array}{l}\text { Serum IgM } \\
\text { concentration }\end{array}$ \\
\hline Firmicutes & -0.17 & 0.30 & 0.30 & 0.17 & -0.07 & 0.04 & -0.20 \\
\hline Proteobacteria & 0.05 & $-0.46^{*}$ & $-0.46^{*}$ & -0.05 & 0.09 & 0.00 & 0.26 \\
\hline Fusobacteria & 0.17 & -0.13 & -0.13 & -0.16 & 0.02 & -0.01 & 0.01 \\
\hline Verrucomicrobia & 0.27 & -0.15 & -0.15 & -0.24 & 0.00 & 0.23 & 0.18 \\
\hline Actinobacteria & 0.08 & -0.01 & -0.01 & -0.13 & 0.05 & -0.04 & -0.21 \\
\hline
\end{tabular}

${ }^{*} P<0.05 ;{ }^{* *} P<0.01$. 
Table 7. Pearson correlation coefficients between the populations of the principal genera on d 14, and growth performance and immunoglobulin indices

\begin{tabular}{lcccrrrr}
\hline & & & & & \multicolumn{2}{c}{ Serum concentration } \\
\cline { 6 - 8 } Genus & ADG & $\begin{array}{c}\text { Total feed } \\
\text { intake }\end{array}$ & $\begin{array}{c}\text { Starter } \\
\text { intake }\end{array}$ & $\begin{array}{c}\text { Feed } \\
\text { efficiency }\end{array}$ & IgG & IgA & IgM \\
\hline Escherichia & -0.19 & 0.15 & 0.15 & 0.16 & 0.02 & 0.07 & 0.16 \\
Bacteroides & 0.04 & -0.23 & -0.23 & -0.03 & -0.12 & -0.12 & -0.13 \\
Butyricicoccus & 0.23 & 0.19 & 0.19 & 0.25 & -0.13 & -0.18 & -0.11 \\
Dorea & 0.03 & 0.14 & 0.14 & 0.031 & $0.42^{*}$ & $0.42^{*}$ & 0.06 \\
Peptostreptococcus & 0.16 & -0.09 & -0.09 & -0.17 & -0.05 & -0.12 & -0.03 \\
Lactobacillus & 0.30 & -0.03 & -0.03 & -0.22 & -0.02 & -0.19 & -0.13 \\
Ruminococcus & -0.08 & -0.27 & -0.27 & 0.02 & -0.20 & -0.21 & -0.16 \\
Faecalibacterium & $0.35^{*}$ & -0.14 & -0.14 & -0.34 & 0.20 & -0.05 & -0.03 \\
Fusobacterium & -0.16 & 0.22 & 0.22 & 0.14 & -0.22 & -0.22 & 0.02 \\
Blautia & -0.04 & $0.36^{*}$ & $0.36^{*}$ & 0.15 & $-0.40 *$ & -0.12 & -0.21 \\
Akkermansia & $0.53^{* *}$ & -0.15 & -0.15 & -0.37 & 0.08 & -0.17 & -0.06 \\
Klebsiella & -0.02 & -0.02 & -0.02 & -0.01 & 0.06 & 0.18 & 0.17 \\
Clostridium & 0.03 & 0.08 & 0.08 & -0.06 & 0.07 & -0.23 & -0.14 \\
Collinsella & 0.31 & 0.02 & 0.02 & -0.27 & 0.11 & -0.04 & -0.25 \\
\hline$* P<0.05 ; * P<0.01$ & $*$ & & & & & &
\end{tabular}

${ }^{*} P<0.05 ;{ }^{* *} P<0.01$.

widely used in the clinical setting as antibacterial, antifungal, anti-cancer, and antiparasitic agents (Butler, 2004; Lee et al., 2014; Olano et al., 2014). In the present study, the population of Actinobacteria was larger in the Zn-Met group.

Faecalibacterium, which is a natural antibiotic and probiotic, is widely used in the field of medicine and food engineering (Gray et al., 1994). Previous research has shown that Faecalibacterium is one of the most abundant butyrate-producing bacterial genera in the gastrointestinal tract (Flint et al., 2012). In addition, it is beneficial to host health because it can inhibit the growth of pathogenic bacteria, such as Escherichia coli and Salmonella (McNeeley et al., 1998; Malik et al., 1999). In the present study, the relative abundance of Faecalibacterium on $\mathrm{d} 7$ was higher in the $\mathrm{ZnO}$ and Zn-Met groups than in the control group. Besides, its relative abundance on d 14 positively correlated with ADG, implying that a low level of zinc supplementation improves the health of newborn calves by altering the composition of the rectal microorganisms. Previous studies have shown that proliferation of Lactobacillus reduces the local $\mathrm{pH}$ in the gastrointestinal system because they produce a large quantity of lactic acid, which inhibits the growth and reproduction of pathogenic bacteria, such as Escherichia coli (Sreekumar and Hosono, 2000; Lin et al., 2009). Moreover, the lactate can also be converted to butyrate, which maintains the acidity of the environment and suppresses the growth of pathogens in the intestinal tract. It has been shown previously that the administration of an appropriate amount of $\mathrm{ZnO}$ increases the relative abundance of Lactobacillus (Starke et al., 2014), and this effect has been confirmed in the present study. Ruminococcus is one of the most important microbes in the rumen of ruminants because it is capable of degrading cellulose (La Reau et al., 2016). Collinsella can metabolize carbohydrates of plant or animal origin, and together with Bifidobacterium, it modifies the bile acids of the host, which modulates the virulence and pathogenicity of enteric pathogens (Bag et al., 2017). The relative abundances of these bacteria were higher in calves supplemented with Zn-Met on d 14 and 7, respectively.

\section{CONCLUSIONS}

We demonstrated that supplementation with a low dose of zinc, obtained from Zn-Met, promoted growth performance and reduced the incidence of diarrhea in calves during their first $14 \mathrm{~d}$ of life. Supplementation with the same quantity of zinc in the form of $\mathrm{ZnO}$ had similar effects as Zn-Met, but no significant differences were identified between the $\mathrm{ZnO}$ and control groups with respect to these end points. This implies that Zn-Met has relatively higher bioavailability than $\mathrm{ZnO}$. However, supplementation with $\mathrm{ZnO}$ reduced the incidence of neonatal calf diarrhea during the first $3 \mathrm{~d}$ after birth and increased serum IgG and IgM concentrations during the first 2 wk of life. The rectal microbial composition was not affected by supplementation with either zinc source, but changed significantly as the calves grew older. Therefore, we infer that the lower incidence of diarrhea in calves receiving a zinc supplement is not the result of an effect on rectal microbial composition or diversity. In view of their differing effects, we recommend that $\mathrm{ZnO}$ be administered to dairy calves during their first $3 \mathrm{~d}$ of life and that Zn-Met is administered subsequently. Our findings provide a basis for the ratio- 
nal use of dietary zinc supplementation in calf production and may help to reduce the use of antibacterial agents.

\section{ACKNOWLEDGMENTS}

This study was financially supported by the National Key Research and Development Program of China (2017YFD0500502; 2018YFD0500703), the Agricultural Science and Technology Innovation Program (ASTIPIAS07, Beijing, China), and the Scientific Research Project for Major Achievements of the Agricultural Science and Technology Innovation Program (ASTIP; no. CAAS-ZDXT2019004, Beijing, China). The authors declare that the research was performed without any commercial or financial relationships that could be construed as potential conflicts of interest.

\section{REFERENCES}

AOAC International. 2000. Official Methods of Analysis. 17th ed. AOAC International, Arlington, MA.

AOAC International. 2003. Official Methods of Analysis. 17th ed. AOAC International, Gaithersburg, MD.

AOAC International. 2005. Official Methods of Analysis. 18th ed. AOAC International, Washington, DC.

Bag, S., T. S. Ghosh, and B. Das. 2017. Complete genome sequence of Collinsella aerofaciens isolated from the gut of a healthy Indian subject. Genome Announc. 5:e01361-17. https://doi.org/10.1128/ genomeA.01361-17.

Bednorz, C., K. Oelgeschläger, B. Kinnemann, S. Hartmann, K. Neumann, R. Pieper, A. Bethe, T. Semmler, K. Tedin, P. Schierack, L. H. Wieler, and S. Guenther. 2013. The broader context of antibiotic resistance: Zinc feed supplementation of piglets increases the proportion of multi-resistant Escherichia coli in vivo. Int. J. Med. Microbiol. 303:396-403. https://doi.org/10.1016/j.ijmm.2013.06 .004 .

Bonaventura, P., G. Benedetti, F. Albarède, and P. Miossec. 2015. Zinc and its role in immunity and inflammation. Autoimmun. Rev. 14:277-285. https://doi.org/10.1016/j.autrev.2014.11.008.

Butler, M. S. 2004. The role of natural products chemistry in drug discovery. J. Nat. Prod. 67:2141-2153. https://doi.org/10.1021/ np040106y.

Berni Canani, R., V. Buccigrossi, and A. Passariello. 2011. Mechanisms of action of zinc in acute diarrhea. Curr. Opin. Gastroenterol. 27:8-12. https://doi.org/10.1097/MOG.0b013e32833fd48a.

Cani, P. D., J. Amar, M. A. Iglesias, M. Poggi, C. Knauf, D. Bastelica, A. Neyrinck, F. Fava, K. Tuohy, C. Chabo, A. Waget, E. Delmée, B. Cousin, T. Sulpice, B. Chamontin, J. Ferrières, J. Tanti, G. Gibson, L. Casteilla, N. Delzenne, M. Alessi, and R. Burcelin. 2007. Metabolic endotoxemia initiates obesity and insulin resistance. Diabetes 56:1761-1772. https://doi.org/10.2337/db06-1491.

Caporaso, J. G., J. Kuczynski, J. Stombaugh, K. Bittinger, F. D. Bushman, E. K. Costello, N. Fierer, A. G. Peña, J. K. Goodrich, J. I. Gordon, G. A. Huttley, S. T. Kelley, D. Knights, J. E. Koenig, R. E. Ley, C. A. Lozupone, D. Mcdonald, B. D. Muegge, M. Pirrung, J. Reeder, J. R. Sevinsky, P. J. Turnbaugh, W. A. Walters, J. Widmann, T. Yatsunenko, J. Zaneveld, and R. Knight. 2010. QIIME allows analysis of high-throughput community sequencing data. Nat. Methods 7:335-336. https://doi.org/10.1038/nmeth.f 303.

Chagas, J. C. C., M. A. Ferreira, A. P. Faciola, F. S. Machado, M. M. Campos, M. R. Entjes, J. L. Donzele, and M. I. Marcondes. 2018. Effects of methionine plus cysteine inclusion on performance and body composition of liquid-fed crossbred calves fed a commercial milk replacer and no starter feed. J. Dairy Sci. 101:6055-6065. https://doi.org/10.3168/jds.2017-13615.

Crassini, K. R., E. Zhang, S. Balendran, J. A. Freeman, O. G. Best, C. J. Forsyth, N. J. Mackinlay, P. Han, W. S. Stevenson, and S. P. Mulligan. 2018. Humoral immune failure defined by immunoglobulin class and immunoglobulin G subclass deficiency is associated with shorter treatment-free and overall survival in chronic lymphocytic leukaemia. Br. J. Haematol. 181:97-101. https://doi .org/10.1111/bjh.15146.

Edgar, R. C., B. J. Haas, J. C. Clemente, C. Quince, and R. Knight. 2011. UCHIME improves sensitivity and speed of chimera detection. Bioinformatics 27:2194-2200. https://doi.org/10.1093/ bioinformatics/btr381.

Ehrenstein, M. R., and C. A. Notley. 2010. The importance of natural IgM: Scavenger, protector and regulator. Nat. Rev. Immunol. 10:778-786. https://doi.org/10.1038/nri2849.

El-Nour, H. H. M., H. M. A. A. Rahman, and S. A. Elwakeel. 2010. Effect of zinc-methionine supplementation on reproductive performance, kid's performance, minerals profile and milk quality in early lactating Baladi goats. World Appl. Sci. J. 9:275-282. https: //doi.org/10.1016/j.anifeedsci.2018.06.011.

El-Seedy, F. R., A. H. Abed, H. A. Yanni, and S. A. A. Abd ElRahman. 2016. Prevalence of Salmonella and E. coli in neonatal diarrheic calves. BNBAS 5:45-51. https://doi.org/10.1016/j.bjbas 2015.11.010.

Fairbrother, J. M., E. Nadeau, and C. L. Gyles. 2005. Escherichia coli in postweaning diarrhea in pigs: an update on bacterial types, pathogenesis, and prevention strategies. Anim. Health Res. Rev. 6:17-39. https://doi.org/10.1079/AHR2005105.

Feldmann, H. R., D. R. Williams, J. D. Champagne, T. W. Lehenbauer, and S. S. Aly. 2019. Effectiveness of zinc supplementation on diarrhea and average daily gain in pre-weaned dairy calves: A double-blind, block-randomized, placebo-controlled clinical trial. PLoS One 14:e0219321. https://doi.org/10.1371/journal.pone .0219321.

Flint, H. J., K. P. Scott, S. H. Duncan, P. Louis, and E. Forano. 2012. Microbial degradation of complex carbohydrates in the gut. Gut Microbes 3:289-306. https://doi.org/10.4161/gmic.19897.

Garg, A. K., V. Mudgal, and R. S. Dass. 2008. Effect of organic zinc supplementation on growth, nutrient utilization and mineral profile in lambs. Anim. Feed Sci. Technol. 144:82-96. https://doi.org/ 10.1016/j.anifeedsci.2007.10.003.

Glover, A. D., B. Puschner, H. A. Rossow, T. W. Lehenbauer, J. D. Champagne, P. C. Blanchard, and S. S. Aly. 2013. A double-blind block randomized clinical trial on the effect of zinc as a treatment for diarrhea in neonatal Holstein calves under natural challenge conditions. Prev. Vet. Med. 112:338-347. https://doi.org/10.1016/ j.prevetmed.2013.09.001.

Gray, J., P. T. Marsh, D. Stewart, and S. J. Pedler. 1994. Enterococcal bacteraemia: A prospective study of 125 episodes. J. Hosp. Infect. 27:179-186. https://doi.org/10.1016/0195-6701(94)90125-2.

Haas, B. J., D. Gevers, A. M. Earl, M. Feldgarden, D. V. Ward, G. Giannoukos, D. Ciulla, D. Tabbaa, S. K. Highlander, E. Sodergren, B. Methé, T. Z. DeSantis, J. F. Petrosino, R. Knight, B. W. Birren, and Human Microbiome Consortium. 2011. Chimeric 16S rRNA sequence formation and detection in Sanger and 454-pyrosequenced PCR amplicons. Genome Res. 21:494-504. https://doi .org/10.1101/gr.112730.110.

Heinrichs, A. J., and B. S. Heinrichs. 2011. A prospective study of calf factors affecting first-lactation and lifetime milk production and age of cows when removed from the herd. J. Dairy Sci. 94:336-341. https://doi.org/10.3168/jds.2010-3170.

Hill, G. M., D. C. Mahan, and J. S. Jolliff. 2014. Comparison of organic and inorganic zinc sources to maximize growth and meet the zinc needs of the nursery pig. J. Anim. Sci. 92:1582-1594. https:/ /doi.org/10.2527/jas.2013-6744.

Hill, T. M., H. G. Bateman II, J. M. Aldrich, R. L. Schlotterbeck, and K. G. Tanan. 2008. Optimal concentrations of lysine, methionine, and threonine in milk replacers for calves less than five weeks of age. J. Dairy Sci. 91:2433-2442. https://doi.org/10.3168/jds.2007 -0610 . 
Hojberg, O., N. Canibe, H. D. Poulsen, M. S. Hedemann, and B. B. Jensen. 2005. Influence of dietary zinc oxide and copper sulfate on the gastrointestinal ecosystem in newly weaned piglets. Appl. Environ. Microbiol. 71:2267-2277. https://doi.org/10.1128/AEM 71.5.2267-2277.2005.

Hu, C. H., K. Xiao, J. Song, and Z. S. Luan. 2013. Effects of zinc oxide supported on zeolite on growth performance, intestinal microflora and permeability, and cytokines expression of weaned pigs. Anim. Feed Sci. Technol. 181:65-71. https://doi.org/10.1016/j.anifeedsci 2013.02.003.

Ishaq, S. L., C. M. Page, C. J. Yeoman, T. W. Murphy, M. L. Van Emon, and W. C. Stewart. 2019. Zinc AA supplementation alters yearling ram rumen bacterial communities but zinc sulfate supplementation does not. J. Anim. Sci. 97:687-697. https://doi.org/10 $.1093 / \mathrm{jas} / \mathrm{sky} 456$.

Jankowski, J., M. Kubińska, and Z. Zduńczyk. 2014. Nutritional and immunomodulatory function of methionine in poultry diets- $\mathrm{A}$ review. Ann. Anim. Sci. 14:17-32. https://doi.org/10.2478/aoas -2013-0081.

Keen, C. L., and M. E. Gershwin. 1990. Zinc deficiency and immune function. Annu. Rev. Nutr. 10:415-431. https://doi.org/10.1146/ annurev.nu.10.070190.002215.

Kegley, E. B., S. A. Silzell, D. L. Kreider, D. L. Galloway, K. P. Coffey, J. A. Hornsby, and D. S. Hubbell III.. 2001. The immune response and performance of calves supplemented with zinc from an organic and an inorganic source. Prof. Anim. Sci. 17:33-38. https://doi .org/10.15232/S1080-7446(15)31593-X.

Kim, Y. S., and J. A. Milner. 2007. Dietary modulation of colon cancer risk. J. Nutr. 137:2576S-2579S. https://doi.org/10.1093/jn/137.11 $.2576 \mathrm{~S}$.

Lee, L. H., N. Zainal, A. S. Azman, S. K. Eng, B. H. Goh, W. F. Yin, N. S. Ab Mutalib, and K. G. Chan. 2014. Diversity and antimicrobial activities of Actinobacteria isolated from tropical mangrove sediments in Malaysia. ScientificWorldJournal 2014:698178. https: //doi.org/10.1155/2014/698178.

Liberato, S. C., G. Singh, and K. Mulholland. 2015. Zinc supplementation in young children: A review of the literature focusing on diarrhoea prevention and treatment. Clin. Nutr. 34:181-188. https:// doi.org/10.1016/j.clnu.2014.08.002.

Lin, P., Y. Hsieh, and C. Tsai. 2009. Antagonistic activity of Lactobacillus acidophilus RY2 isolated from healthy infancy feces on the growth and adhesion characteristics of enteroaggregative Escherichia coli. Anaerobe 15:122-126. https://doi.org/10.1016/j .anaerobe.2009.01.009.

Magoč, T., and S. L. Salzberg. 2011. FLASH: Fast length adjustment of short reads to improve genome assemblies. Bioinformatics 27:2957-2963. https://doi.org/10.1093/bioinformatics/btr507.

Malik, R. K., M. A. Montecalvo, M. R. Reale, K. Li, M. Maw, J. L. Munoz, C. Gedris, K. van Horn, K. A. Carnevale, M. H. Levi, and H. S. Dweck. 1999. Epidemiology and control of vancomycin-resistant enterococci in a regional neonatal intensive care unit. Pediatr. Infect. Dis. J. 18:352-356. https://doi.org/10.1097/00006454 -199904000-00009.

Marcondes, M. I., T. R. Pereira, J. C. C. Chagas, E. A. Filgueiras, M. M. D. Castro, G. P. Costa, A. L. Sguizzato, and R. D. Sainz. 2016. Performance and health of Holstein calves fed different levels of milk fortified with symbiotic complex containing pre- and probiotics. Trop. Anim. Health Prod. 48:1555-1560. https://doi.org/10 $.1007 / \mathrm{s} 11250-016-1127-1$.

Mattioli, G. A., D. E. Rosa, E. Turic, A. E. Relling, E. Galarza, and L. E. Fazzio. 2018. Effects of copper and zinc supplementation on weight gain and hematological parameters in pre-weaning calves. Biol. Trace Elem. Res. 185:327-331. https://doi.org/10.1007/ s12011-017-1239-0.

Mazmanian, S. K., J. L. Round, and D. L. Kasper. 2008. A microbial symbiosis factor prevents intestinal inflammatory disease. Nature 453:620-625. https://doi.org/10.1038/nature07008.

McNeeley, D. F., A. E. Brown, G. J. Noel, M. Chung, and L. De Lencastre. 1998. An investigation of vancomycin-resistant enterocicci faecium within the pediatric service of a large urban medical cen- ter. Pediatr. Infect. Dis. J. 17:184-188. https://doi.org/10.1097/ 00006454-199803000-00003.

Morrison, L. A. 2011. Chapter 2 - Dystrophinopathies. Handb. Clin. Neurol. 101:11-39. https://doi.org/10.1016/B978-0-08-045031-5 $.00002-5$.

Nagalakshmi, D., K. Sridhar, M. Satyanarayana, S. Parashu Ramulu, V. S. Narwade, and L. Vikram. 2018. Effect of replacing inorganic zinc with a lower level of organic zinc (zinc propionate) on performance, biochemical constituents, antioxidant, immune and mineral status in buffalo calves. Indian J. Anim. Res. 52:1292-1297. https: //doi.org/10.18805/ijar.B-3362.

Nayeri, A., N. C. Upah, E. Sucu, M. V. Sanz-Fernandez, J. M. DeFrain, P. J. Gorden, and L. H. Baumgard. 2014. Effect of the ratio of zinc amino acid complex to zinc sulfate on the performance of Holstein cows. J. Dairy Sci. 97:4392-4404. https://doi.org/10 $.3168 /$ jds.2013-7541.

Olano, C., I. García, A. González, M. Rodriguez, D. Rozas, J. Rubio, M. Sánchez-Hidalgo, A. F. Braña, C. Méndez, and J. A. Salas. 2014. Activation and identification of five clusters for secondary metabolites in Streptomyces albus J1074. Microb. Biotechnol. 7:242-256. https://doi.org/10.1111/1751-7915.12116.

Oteiza, P. I., and G. G. Mackenzie. 2005. Zinc, oxidant-triggered cell signaling, and human health. Mol. Aspects Med. 26:245-255. https://doi.org/10.1016/j.mam.2005.07.012.

Pal, D. T., N. K. S. Gowda, C. S. Prasad, R. Amarnath, U. Bharadwaj, G. Suresh Babu, and K. T. Sampath. 2010. Effect of copperand zinc-methionine supplementation on bioavailability, mineral status and tissue concentrations of copper and zinc in ewes. J. Trace Elem. Med. Biol. 24:89-94. https://doi.org/10.1016/j.jtemb 2009.11.007.

Pei, X., Z. Xiao, L. Liu, G. Wang, W. Tao, M. Wang, J. Zou, and D. Leng. 2019. Effects of dietary zinc oxide nanoparticles supplementation on growth performance, zinc status, intestinal morphology, microflora population, and immune response in weaned pigs. J. Sci. Food Agric. 99:1366-1374. https://doi.org/10.1002/jsfa.9312.

Pettigrew, J. E. 2006. Reduced use of antibiotic growth promoters in diets fed to weaning pigs: Dietary tools, part 1. Anim. Biotechnol. 17:207-215. https://doi.org/10.1080/10495390600956946.

Pieper, R., W. Vahjen, K. Neumann, A. G. Van Kessel, and J. Zentek. 2012. Dose-dependent effects of dietary zinc oxide on bacterial communities and metabolic profiles in the ileum of weaned pigs. J. Anim. Physiol. Anim. Nutr. (Berl.) 96:825-833. https://doi.org/10 .1111/j.1439-0396.2011.01231.x.

Pourliotis, K., M. A. Karatzia, P. Florou-Paneri, P. D. Katsoulos, and H. Karatzias. 2012. Effects of dietary inclusion of clinoptilolite in colostrum and milk of dairy calves on absorption of antibodies against Escherichia coli and the incidence of diarrhea. Anim. Feed Sci. Technol. 172:136-140. https://doi.org/10.1016/j.anifeedsci .2011.12.001.

La Reau, A. J., J. P. Meier-Kolthoff, and G. Suen. 2016. Sequencebased analysis of the genus Ruminococcus resolves its phylogeny and reveals strong host association. Microb. Genom. 2:e000099. https://doi.org/10.1099/mgen.0.000099.

Sales, J. 2013. Effects of pharmacological concentrations of dietary zinc oxide on growth of post-weaning pigs: A meta-analysis. Biol. Trace Elem. Res. 152:343-349. https://doi.org/10.1007/s12011 -013-9638-3.

Shen, J., Y. Chen, Z. Wang, A. Zhou, M. He, L. Mao, H. Zou, Q. Peng, B. Xue, L. Wang, X. Zhang, S. Wu, and Y. Lv. 2014. Coated zinc oxide improves intestinal immunity function and regulates microbiota composition in weaned piglets. Br. J. Nutr. 111:2123-2134. https://doi.org/10.1017/S0007114514000300.

Shin, N. R., T. W. Whon, and J. W. Bae. 2015. Proteobacteria: Microbial signature of dysbiosis in gut microbiota. Trends Biotechnol. 33:496-503. https://doi.org/10.1016/j.tibtech.2015.06.011.

Spears, J. W. 1989. Zinc methionine for ruminants: Relative bioavailability of zinc in lambs and effects of growth and performance of growing heifers. J. Anim. Sci. 67:835-843. https://doi.org/10 $.2527 /$ jas $1989.673835 \mathrm{x}$.

Sreekumar, O., and A. Hosono. 2000. Immediate effect of Lactobacillus acidophilus on the intestinal flora and fecal enzymes of rats and 
the in vitro inhibition of Escherichia coli in coculture. J. Dairy Sci. 83:931-939. https://doi.org/10.3168/jds.S0022-0302(00)74956-3.

Starke, I. C., R. Pieper, K. Neumann, J. Zentek, and W. Vahjen. 2014. The impact of high dietary zinc oxide on the development of the intestinal microbiota in weaned piglets. FEMS Microbiol. Ecol. 87:416-427. https://doi.org/10.1111/1574-6941.12233.

Sun, P., J. N. Li, D. P. Bu, X. M. Nan, and H. Du. 2016. Effects of $B a-$ cillus subtilis natto and different components in culture on rumen fermentation and rumen functional bacteria in vitro. Curr. Microbiol. 72:589-595. https://doi.org/10.1007/s00284-016-0986-z.

Sun, Y. B., T. Xia, H. Wu, W. J. Zhang, Y. H. Zhu, J. X. Xue, D. T. He, and L. Y. Zhang. 2019. Effects of nano zinc oxide as an alternative to pharmacological dose of zinc oxide on growth performance, diarrhea, immune responses, and intestinal microflora profile in weaned piglets. Anim. Feed Sci. Technol. 258:114312. https://doi.org/10.1016/j.anifeedsci.2019.114312.

Teixeira, A. G., L. Stephens, T. J. Divers, T. Stokol, and R. C. Bicalho. 2015. Effect of crofelemer extract on severity and consistency of experimentally induced enterotoxigenic Escherichia coli diarrhea in newborn Holstein calves. J. Dairy Sci. 98:8035-8043. https:// doi.org/10.3168/jds.2015-9513.

Tomasi, T., A. Volpato, W. A. B. Pereira, L. H. Debastiani, N. B. Bottari, V. M. Morsch, M. R. C. Schetinger, M. L. R. Leal, G. Machado, and A. S. Da Silva. 2018. Metaphylactic effect of minerals on the immune response, biochemical variables and antioxidant status of newborn calves. J. Anim. Physiol. An. N. 102:819-824. https://doi.org/10.1111/jpn.12890.

Van Soest, P. J., J. B. Robertson, and B. A. Lewis. 1991. Methods for dietary fiber, neutral detergent fiber, and nonstarch polysaccharides in relation to animal nutrition. J. Dairy Sci. 74:3583-3597. https://doi.org/10.3168/jds.S0022-0302(91)78551-2.

Wagner, B. 2017. Death loss in U.S. cattle and calves due to predator and nonpredator causes. 2015. The report of USDA. USDA APHIS. Accessed Mar. 31, 2020. https://www.aphis.usda.gov/animal _health/nahms/general/downloads/cattle_calves_deathloss_2015 .pdf.

Wang, B., C. T. Yang, Q. Y. Diao, and Y. Tu. 2018a. The influence of mulberry leaf flavonoids and candida tropicalis on antioxidant function and gastrointestinal development of preweaning calves challenged with Escherichia coli O141:K99. J. Dairy Sci. 101:60986108. https://doi.org/10.3168/jds.2017-13957.

Wang, J., Y. X. Zeng, S. X. Wang, H. Liu, D. Y. Zhang, W. Zhang, Y. Wang, and H. Ji. 2018b. Swine-derived probiotic Lactobacillus plantarum inhibits growth and adhesion of Enterotoxigenic Escherichia coli and mediates host defense. Front. Microbiol. 9:1364. https://doi.org/10.3389/fmicb.2018.01364.

Wang, Q., G. M. Garrity, J. M. Tiedje, and J. R. Cole. 2007. Naive bayesian classifier for rapid assignment of rRNA sequences into the new bacterial taxonomy. Appl. Environ. Microbiol. 73:5261-5267. https://doi.org/10.1128/AEM.00062-07.

Wei, J. Y., F. T. Ma, L. Y. Hao, Q. Shan, and P. Sun. 2019. Effect of differing amounts of zinc oxide supplementation on the antioxidant status and zinc metabolism in newborn dairy calves. Livest. Sci. 230:103819. https://doi.org/10.1016/j.livsci.2019.103819.

Wen, L., R. E. Ley, P. Y. Volchkov, P. B. Stranges, L. Avanesyan, A. Stonebraker, C. Hu, S. F. Wong, G. L. Szot, J. A. Bluestone, J. I. Gordon, and A. V. Chervonsky. 2008. Innate immunity and intestinal microbiota in the development of Type 1 diabetes. Nature 455:1109-1113. https://doi.org/10.1038/nature07336.

Wessels, I., M. Maywald, and L. Rink. 2017. Zinc as a gatekeeper of immune function. Nutrients 9:1286. https://doi.org/10.3390/ nu9121286.

Woof, J. M., and M. A. Kerr. 2006. The function of immunoglobulin A in immunity. J. Pathol. 208:270-282. https://doi.org/10.1002/ path.1877.

Wu, G., W. G. Pond, T. Ott, and F. W. Bazer. 1998. Maternal dietary protein deficiency decreases amino acid concentrations in fetal plasma and allantoic fluid of pigs. J. Nutr. 128:894-902. https:// doi.org/10.1093/jn/128.5.894.

\section{ORCIDS}

P. Sun (1) https://orcid.org/0000-0002-2370-265X 